\title{
Ovine corpus luteum proteins, with functions including oxidative stress and lipid metabolism, show complex alterations during implantation
}

\author{
Mitra Arianmanesh ${ }^{1,2}$, Rebecca H McIntosh ${ }^{3}$, Richard G Lea ${ }^{4}$, Paul A Fowler ${ }^{1}$ and Kaïs H Al-Gubory ${ }^{5}$ \\ ${ }^{1}$ Division of Applied Medicine, Institute of Medical Sciences, Centre for Reproductive Endocrinology and Medicine, University of Aberdeen, Foresterhill, \\ Aberdeen AB25 2ZD, UK \\ ${ }^{2}$ Department of Anatomical Sciences, School of Medicine, Zanjan University of Medical Sciences, Zanjan 45156-13191, Iran \\ ${ }^{3}$ School of Medical Sciences, Institute of Medical Sciences, University of Aberdeen, Aberdeen AB25 2ZD, UK \\ ${ }^{4}$ School of Veterinary Medicine and Science, University of Nottingham, Sutton Bonington, LE12 5RD, UK \\ ${ }^{5}$ UMR 1198, Biologie du Développement et de la Reproduction, Département de Physiologie Animale et Systèmes d'Elevage, Institut National de la Recherche \\ Agronomique (INRA), F78350 Jouy-en-Josas, France \\ (Correspondence should be addressed to M Arianmanesh at Division of Applied Medicine, Institute of Medical Sciences, Centre for Reproductive Endocrinology \\ and Medicine, University of Aberdeen; Email: m.arianmanseh@abdn.ac.uk)
}

\begin{abstract}
Progesterone $\left(\mathrm{P}_{4}\right)$ secreted by the corpus luteum (CL) is critical for in utero embryo survival and development, although CL proteins are key regulatory factors during the luteal phase. We, therefore, characterised protein expression patterns in ovine CL of pregnancy (days 12,16 and 20) compared with those of controls, CL of oestrous cycle (days 12 and 16), using two-dimensional gel electrophoresis (2DE) gel-based proteomics. Proteins in 24 significantly altered spots were identified by tandem mass spectroscopy. At the time of embryo implantation (day 16), 77 spots were up-regulated and 101 spots were down-regulated in CL of pregnancy compared with regressed CL. Vimentin, lamin A/C (LMNA), [Mn] superoxide dismutase (SOD2), isocitrate dehydrogenase 1, annexin A1 and elongation factor $\mathrm{Tu}$, mitochondrial (TUFM) altered during CL regression, whereas glutathione S-transferase A1, apolipoprotein A-1, myxovirus resistance protein 1 , ornithine aminotransferase and enoyl-CoA hydratase, mitochondrial (ECHS1) tended to be altered during $\mathrm{CL}$ maintenance. biliverdin reductase $\mathrm{B}$
\end{abstract}

(BLVRB), FDXR, guanine nucleotide-binding protein $\mathrm{G}(\mathrm{I}) / \mathrm{G}(\mathrm{S}) / \mathrm{G}(\mathrm{T})$ subunit beta-2 (GNB2) and cytochrome bc1 complex subunit 1, mitochondrial (UQCRC1) showed divergent expression during CL regression and maintenance. The expression of two representative proteins, SOD2 and BLVRB, by western blot increased in CL of non-pregnant ewes on day 16 compared with that on day 12. SOD2 and BLVRB were localised in the large and small luteal cells and endothelial cells of CL over peri-implantation periods. 2DE gel and mass spectrometry have been used, for the first time, to study ovine CL function. We have identified proteins involved in key pathways, including oxidative stress, steroidogenesis, signal transduction and apoptosis, which have not previously been associated with changes occurring in the CL during the peri-implantation period. These proteins are most likely involved with mechanisms allowing the $\mathrm{CL}$ to produce $\mathrm{P}_{4}$ during early pregnancy.

Journal of Endocrinology (2011) 210, 47-58

\section{Introduction}

In mammals, the corpus luteum $(\mathrm{CL})$ secretes progesterone $\left(\mathrm{P}_{4}\right)$ which is required for the establishment and maintenance of pregnancy. Rescue of the CL from periodic cyclic regression and the maintenance of $\mathrm{P}_{4}$ production are crucial for uterine receptivity and are required for the implantation, survival and development of pre-implantation embryos, eventually leading to successful pregnancy outcomes (Schlafke \& Enders 1975, Niswender et al. 2000). Many locally produced proteins are involved in CL function. Therefore, abnormal expression of luteal components may have adverse effects on the end target, the endometrium, leading to embryo-endometrial asynchrony, disruption of embryo implantation and failure to maintain pregnancy (Tavaniotou et al. 2002, Mitwally et al. 2005). Luteal dysfunction, short luteal phases and subsequent endocrine abnormalities following the induction of ovulation are presumptive causes of early embryonic loss and pregnancy failure in livestock (Wathes 1992, Murdoch \& Van Kirk 1998) and humans (Tavaniotou et al. 2002, Arredondo \& Noble 2006). Defective $\mathrm{P}_{4}$ production and/or inadequate luteal rescue by pituitary luteotrophic factors and trophoblast anti-luteolytic signals, produced by the conceptus during the peri-implantation period, are major causes of embryonic mortality and early recurrent abortions (Arredondo \& Noble 2006) in humans (Porter \& Scott 2005) and ruminants (Diskin \& Morris 2008).

The CL is essential throughout pregnancy in the mouse, rat, hamster, rabbit, dog, sow and goat, but less than full term 
in cat, guinea pig, sheep, cow, horse, macaque and human (Ryan 1969). In the latter species, the placenta subsequently becomes a predominant source of $\mathrm{P}_{4}$. The timing of this change varies between species: relatively early in pregnancy in the human (Csapo et al. 1972) and ovine (Al-Gubory et al. 1999) or during later gestation in bovine (Estergreen et al. 1967). The CL of the oestrous/menstrual cycle exhibits marked structural and functional alterations, depending on a balance between principal luteotrophic and luteolytic signals, $\mathrm{LH}$ and prostaglandin $\mathrm{F}_{2 \alpha}\left(\mathrm{PGF}_{2 \alpha}\right)$ respectively (Vonnahme et al. 2006). In the absence of fertilization, the CL exhibits short periodic growth and differentiation followed by luteal regression, characterised by the loss of $\mathrm{P}_{4}$ secretion and apoptosis (Al-Gubory et al. 2005, Vonnahme et al. 2006). Although several factors are known to be involved in the regulation of luteal growth and regression, these processes are not fully understood (Webb et al. 2002).

Much of the molecular data on CL formation, function and regression originate from genomic and transcriptomic studies, partly due to limited availability of protein tools, such as suitable antibodies (Gonzalez-Fernandez et al. 2008). However, one of the main problems with genomic studies is that gene expression and biological effects are associated with complex protein synthesis. It is not necessarily possible to accurately predict protein expression patterns from mRNA due to post-transcriptional mechanisms (mRNA export, surveillance, silencing and turnover) and post-translational modifications, which can determine protein activity, localisation, turnover and interactions with other proteins (Mann \& Jensen 2003). Therefore, the application of proteomics is important for the understanding of physiological and biological processes (Fowler et al. 2007). We aimed to identify CL proteins altering during the peri-implantation periods of pregnant ewes compared with matching stages of the luteal phase of cyclic ewes in order to facilitate better understanding of the molecular mechanisms underlying CL regression and maintenance.

\section{Materials and Methods}

\section{Animals and sample collection}

The French Ministry of Agriculture approved all procedures relating to the care and use of animals according to regulations for animal experimentation (authorization no. 78-34). All ewes (Préalpes-du-Sud breed, 18 months of age) were treated for 14 days with intra-vaginal sponges containing $40 \mathrm{mg}$ fluorogestone (Intervet, Angers, France) to synchronise oestrous. An i.m. injection of $400 \mathrm{IU}$ equine chorionic gonadotropin (Intervet) was administered to each ewe immediately after the removal of the sponges. Ewes assigned to the pregnant group were mated twice at oestrous with fertile rams, at an interval of $12 \mathrm{~h}$. Pregnancy was confirmed by recovery of a visibly normal conceptus (embryo and associated extra-embryonic membranes) in uterine flashings using $20 \mathrm{ml}$ sterile PBS, $\mathrm{pH} 7 \cdot 4$. Pregnant ewes $(n=12)$ were killed according to the protocols approved by the local INRA animal use committee on days 12 (pre-implantation, P12), 16 (implantation, P16) and 20 (post-implantation, P20) of pregnancy $(n=4$ ewes per group). A total of eight nonmated ewes used as controls were killed on days 12 (C12, $n=4$ ewes) and 16 (C16, $n=4$ ewes) of the oestrous cycle. After killing, the reproductive tracts were collected and immediately transported to the laboratory where the CLs were dissected from the surrounding ovarian tissue. For immunohistochemistry, a piece of each CL tissue was fixed in freshly prepared $4 \%$ paraformaldehyde in PBS, $\mathrm{pH} 7 \cdot 4$, for $24 \mathrm{~h}$ and embedded in wax. The rest of the CL was snap-frozen in liquid nitrogen and stored at $-80{ }^{\circ} \mathrm{C}$ to be processed for two-dimensional gel electrophoresis (2DE) and western blot.

$P_{4}$ assay

Blood samples were obtained from the jugular veins of the cyclic (days 12 and 16) and pregnant ewes (days 12, 16 and 20) into evacuated heparinised tubes. After centrifugation $\left(3000 \mathrm{~g}, 4^{\circ} \mathrm{C}\right)$ for $30 \mathrm{~min}$, plasma was stored at $-20^{\circ} \mathrm{C}$ until assayed. The concentrations of $\mathrm{P}_{4}$ were determined by RIA in unextracted plasma as described (Schanbacher 1979) and validated for sheep jugular venous plasma (Al-Gubory et al. 2005) with slight modifications (Al-Gubory et al. 2006). Tritiated $\mathrm{P}_{4}(1,2,6$, $7-{ }_{-}^{3} \mathrm{H}_{-} \mathrm{P}_{4}$, sp act $88 \mathrm{Ci} / \mathrm{mmol}$ ) was obtained from Amersham, and a specific anti- $\mathrm{P}_{4}$ antibody was obtained from the Institut Pasteur (Paris, France). All plasma samples were analysed in a single RIA. The limit of assay sensitivity was $0 \cdot 1 \mathrm{ng} / \mathrm{ml}$ and the intra-assay coefficient of variation was $<10 \%$.

\section{Preparation of tissue samples for electrophoretic analyses}

Luteal tissues were combined with $5 \mu \mathrm{l}$ lysis buffer per $1 \mathrm{mg}$ wet weight of tissue (Fowler et al. 2007) and disrupted using a tissue lyser (Qiagen Ltd) for $4 \mathrm{~min}$. Insoluble materials were removed from the lysates by centrifugation for $30 \mathrm{~min}$ $\left(50000 \mathrm{~g}\right.$ at $\left.4{ }^{\circ} \mathrm{C}\right)$. The protein concentration of the supernatants was determined using the Bio-Rad RC-DC protein assay (Bio-Rad) and proteins were stored at $-80{ }^{\circ} \mathrm{C}$ for further analysis.

\section{$2 D E$ analysis}

We selected 2DE for the proteomic analysis because it is a powerful and flexible technique for investigation of protein expression in multiple sample groups (Stephens et al. 2010). Equal amounts of protein from each ewe, in each group, were combined to make five protein pools as follows: cyclic ewes on days 12 (C12) and 16 (C16) and pregnant ewes on days 12 (P12), 16 (P16), and 20 (P20). 2DE was performed as described previously (Cash \& Kroll 2003, Uwins et al. 2006). For first dimension separation, $200 \mu \mathrm{g}$ total protein from CL lysate was loaded on $11 \mathrm{~cm}$, immobilised, non-linear $\mathrm{pH}$ gradient strips of $\mathrm{pH} 3-10$ (Bio-Rad). The second dimension was carried out using $16 \mathrm{~cm} 10 \%$ polyacrylamide gels. 
Quadruplicate 2DE gels were prepared for each of the five groups. Proteins were visualised using Colloidal CBB G-250 and scanned using a Molecular Dynamics Personal Densitometer SI (Molecular Dynamics LTD, Bucks, England) at $50 \mu \mathrm{m}$ resolution to produce 12 bit images. Protein spot profiles were analysed using Progenesis SameSpots version 3 Software (Nonlinear Dynamics Ltd, Newcastle upon Tyne, UK). This software allows very robust analysis of 2DE gels (Silva et al. 2010) using automated spot detection algorithms. Spot numbers assigned by the software at the start of image analysis were retained throughout the study to reduce potential errors. A reference gel was selected and the other gels were aligned to be closely matched to this reference gel using semi-automated procedures. Every spot included in the study was visually checked for reproducibility and robust selection. Background (based on all non-spot areas of the gel) was individually subtracted from each gel and spot volumes were normalised relative to gel total spot volume individually for each gel. Virtual 'average gels' were generated from the four sets of the gels in each group and then used to compare the log-normalised protein spot volumes (ANOVA) between groups. In order to be considered suitable for inclusion in the experiment, the 1409 spots included in this study had to conform to criteria of robust reproducibility and accuracy of the semi-automated spot outlining routines among all four replicate gels for each group. To be considered significantly different, log-normalised spot volumes had to differ between two groups at the level of $P<0.05$ by ANOVA and post hoc testing. In addition, the 24 protein spots selected for identification by liquid chromatography-tandem mass spectrometry (LC-MS/MS) had to include a difference of a $\geq 1 \cdot 25$-fold increase or decrease between two groups and be sufficiently intensely stained to allow a high probability of a positive identification.

\section{Mass spectrometry}

In order to identify proteins, spots were excised from stained gels and subjected to in-gel trypsin digestion as described previously (Uwins et al. 2006). The peptide fragment mass spectra were acquired on a PerSeptive Biosystems Voyager-DE STR MALDI-TOF mass spectrometer operated in the reflection delayed extraction mode. Tryptic peptides from the MS/MS spectra were applied to search the National Centre for Biotechnology Information (NCBI) database with the MASCOT program (http://www.matrixscience.com). Search parameters for the programme that included maximum allowed error of peptide mass $250 \mathrm{ppm}$, cysteine as $S$-carbamidomethyl derivative and oxidation of methionine were allowed.

\section{Western blot}

Individual $\mathrm{CL}$ lysates were loaded (30 $\mu \mathrm{g}$ protein/lane) onto 26-lane 1DE gels (NUPAGE Novex Midi gels, 4-12\%, Invitrogen) under reducing conditions and then electroblotted onto immobilon-FL membrane (Millipore (UK) Ltd., Watford,
UK) as described previously (Fowler et al. 2008). After blotting, membranes were incubated in blocking buffer, 1:1 Odyssey blocking buffer (LI-COR Biosciences UK Ltd, Cambridge, UK) and PBS, at $4{ }^{\circ} \mathrm{C}$ overnight. Primary antibodies were diluted in Odyssey blocking buffer 1:1 with $0 \cdot 2 \mu \mathrm{m}$ filtered PBST as follows: mouse anti-superoxide dismutase $[\mathrm{Mn}]$ (SOD2: Abnova Corp, Taipei, Taiwan, H00006648), 1-2500, and mouse anti-biliverdin reductase B (BLVRB, Abnova Corp, H00000645), 1-1000, all combined with an anti- $\alpha$ tubulin load control (mouse 1-10 000 ab7291, AbCam Ltd, Cambridge, UK). The membranes were incubated with primary antibodies at $4{ }^{\circ} \mathrm{C}$ overnight and then incubated with secondary antibodies for $60 \mathrm{~min}$ at room temperature. Secondary antibodies including anti-mouse IgG IRDYe800 (all secondary antibodies were provided from LI-COR, 610-732-124), 1-10000, and anti-mouse IRDYe700DX (610-730-124) 1-5000, were diluted in Odyssey blocking buffer $1: 1$ with $0 \cdot 2 \mu \mathrm{m}$ filtered PBST $+0.01 \%$ SDS. Following the washing of membranes, the digital images were captured using Odyssey LI-COR Infrared Imager (LI-COR). The band volumes and molecular weights $(\mathrm{kDa})$ were then obtained following a background subtraction using Phoretix-1D Advanced Software (Nonlinear Dynamics). Initially, we tested anti- $\beta$-actin (mouse: $1-5000$ and rabbit: $1-$ 10 000, both AbCam Ltd, ab6227 and ab8227 respectively) and then anti-GAPDH (rabbit: 1-5000, AbCam Ltd, ab9485) as load controls. However, the band volumes of $\beta$-actin and GAPDH were significantly different between the groups, demonstrating the unsuitability of these as load controls. In contrast, $\boldsymbol{\alpha}$-tubulin showed no significant differences $(P>0 \cdot 05)$ between groups and was, therefore, employed as our load control.

\section{Immunohistochemistry}

CL sections of all groups: control groups on days 12 and 16 and pregnant groups on days 12,16 and $20(5 \mu \mathrm{m}$, two sections per slide) were either stained with haematoxylin and eosin (H\&E) or mounted onto ChemMate slides (DakoCytomation Ltd, Ely, UK) and stained using the Bond-maX (Leica Microsystems Newcastle Ltd., Newcastle Upon Tyne, UK) automated immunostaining machine. For immunostaining, two consecutive sections ( $5 \mu \mathrm{m}$ thickness) from all groups were used: one section for main antibody (SOD2/BLVRB) and the other for $3 \beta$-hydroxysteroid dehydrogenase $(3 \beta \mathrm{HSD})$ to label steroidogenic cells. Antigen retrieval $\left(72{ }^{\circ} \mathrm{C}\right.$ in EDTA-based buffer, $\mathrm{pH} 8.8$ ) was performed in situ in the autostainer. Bond Polymer 3,3'-diaminobenzidine (DAB) Detection and Bond Polymer alkaline phosphatase (AP) Red Detection were employed to visualise the sections with $\mathrm{DAB}$ and $\mathrm{AP}$ staining respectively. For DAB staining, endogenous peroxidase activity was blocked using HRP for $10 \mathrm{~min}$. The sections were then incubated with primary antibodies for $40 \mathrm{~min}$ and the Bond DAB Enhancer was used to maximise the level of staining intensity and to create a counterstaining between chromogen-specific staining and the haematoxylin. 
The two antibodies used for DAB staining were i) SOD2 (1:500, with antigen retrieval: mouse polyclonal, Abnova Corp, H00006648) and ii) BLVRB (1:200, with antigen retrieval: mouse polyclonal, Abnova Corp, H00000645). Sections were visualised with Bond 'Refine' DAB, washed in water and counterstained with haematoxylin. For AP staining, the sections were incubated with primary antibody for $30 \mathrm{~min}$. Then, the slides were incubated in post-primary antibody solution for $20 \mathrm{~min}$ and in poly-AP anti-mouse/rabbit $\mathrm{IgG}$ for $30 \mathrm{~min}$. To visualise the desired antigen via a red precipitate, a substrate, chromogen, Fast Red, was applied for overall $20 \mathrm{~min}$ and then counterstained by $0 \cdot 02 \%$ haematoxylin for $5 \mathrm{~min}$. For AP staining, 3ßHSD antibody (1:200, with antigen retrieval: rabbit polyclonal, provided by Prof. J Ian Mason) was used. Negative control sections were included, incubated in the absence of the primary antibody, using non-immune serum, showed no positive immunostaining. Slides were assessed using an Olympus BX41 microscope (Olympus Microscopy, Southend-on-Sea, Essex, UK) and Progres CapturePro 2.6 image Software with a Progress C5 attachment (Jenoptik, Jena, Germany). Different cell types of the CL were recognised according to their shapes: large luteal cells (LLCs) and small LCs (SLCs) are round with a central big nucleus and endothelial cells are small and flat (O'Shea et al. 1979).

\section{Statistical analysis}

Normality of data was tested with the Shapiro-Wilk test. Normally distributed data were subjected to one-way ANOVA and Bonferroni-Dun post hoc test using SPSS 17.0 software (IBM Ltd., Portsmouth, UK) to assess significance of differences. Differences were considered to be significant if $P<0 \cdot 05$ and statistical comparisons between specific groups were carried out by Student's $t$-test. The Mann-Whitney unpaired two-sample tests were employed to analyse nonnormally distributed data.

\section{Results}

\section{CL function}

Plasma concentrations of $\mathrm{P}_{4}$ on day 16 of the oestrous cycle were lower $(P=0 \cdot 015)$ than those on day 12 of the oestrous cycle and on days 12, 16 and 20 of pregnancy (Fig. 1). Concentrations of $\mathrm{P}_{4}$ on day 12 of the oestrous cycle were similar to those on days 12, 16 and 20 of pregnancy (Fig. 1).

\section{The CL proteome profile}

Overall 1409 distinct protein spots were located in the 2DE gels, with representative spots shown in Fig. 2A. The numbers of ovine CL protein spots showing statistically significant differences in normalised spot volumes between groups are summarised in Table 1 . Of the 24 protein spots excised for tandem mass spectroscopy, four spots $(74,145,656$ and 1036) did not yield significant hits (MOWSE score $<150$, peptide coverage $<5 \%$ ). Some proteins (vimentin (VIM), glutathione S-transferase (GST), isocitrate dehydrogenase $1\left(\mathrm{NADP}^{+}\right)$, soluble (IDH1), guanine nucleotide-binding protein $\mathrm{G}(\mathrm{I})$ / $\mathrm{G}(\mathrm{S}) / \mathrm{G}(\mathrm{T})$ subunit beta-2 (GNB2), apolipoprotein A-1 (APOA1) and interferon (IFN)-induced GTP-binding protein Mx1 (or myxovirus resistance protein1 (MX1))) were identified in more than a single 2DE protein spot. In order to maximise the accuracy of the analysis, normalised volumes of each spot containing the same protein were combined. This enabled statistical analysis to be performed, not just on individual spots but also on combined spot volumes where they shared a common protein, allowing a more accurate indication of overall abundance of those proteins.

\section{Changes in CL proteins during CL regression}

The greatest number of alterations in spot volumes $(P<0 \cdot 05)$ was observed between the fully functional (day 12) and regressed CL (day 16): 139 protein spots were up-regulated and 69 were down-regulated (15\% of total spots) in the regressed $\mathrm{CL}$ compared with functional $\mathrm{CL}$ (Table 1). The expression of VIM, IDH1, SOD2; Fig. 2B), BLVRB (Fig. 2C), NADPH, adrenodoxin oxidoreductase (mitochondrial FDXR), annexin A1 (ANXA1), cytochrome b-c1 complex subunit 1, mitochondrial (UQCRC1), elongation factor $\mathrm{Tu}$, mitochondrial (TUFM) and GNB2 increased from day 12 to day 16 in CL of cyclic ewes (Table 2). However, only lamin A/C (LMNA) and APOA1 were significantly $(P<0 \cdot 05)$ reduced in CL on day 16 compared with day 12 of the oestrous cycle (Table 2).

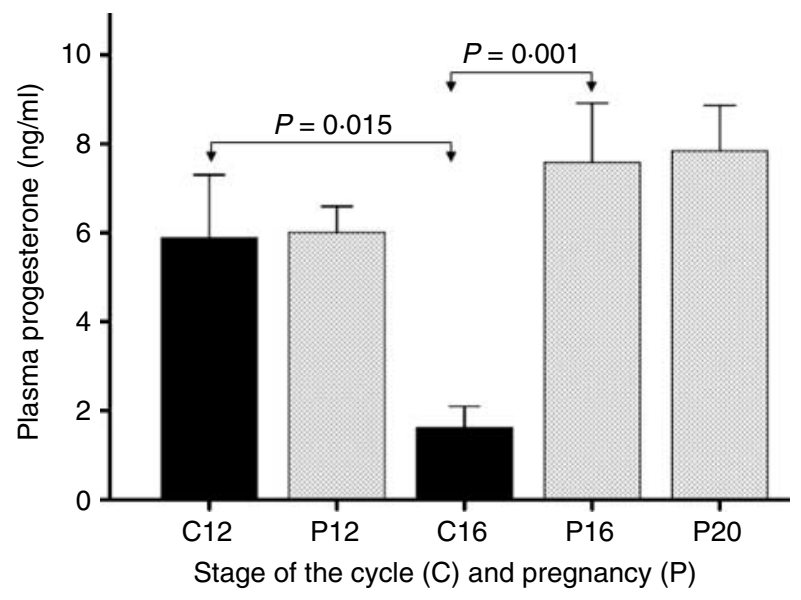

Figure 1 Concentrations of progesterone in plasma of jugular blood collected on days $12(\mathrm{C} 12)$ and 16 (C16) of the oestrous cycle and on days12 (P12), 16 (P16) and 20 (P20) of pregnancy. Progesterone concentrations declined in the plasma at the end of the oestrous cycle (C16) compared with mid luteal phase day (C12). Plasma progesterone concentrations were higher on day P16 than that at matching stage of the oestrous cycle (C16). Values are shown as mean \pm S.E.M. (ng/ml, $n=4$ per group). 

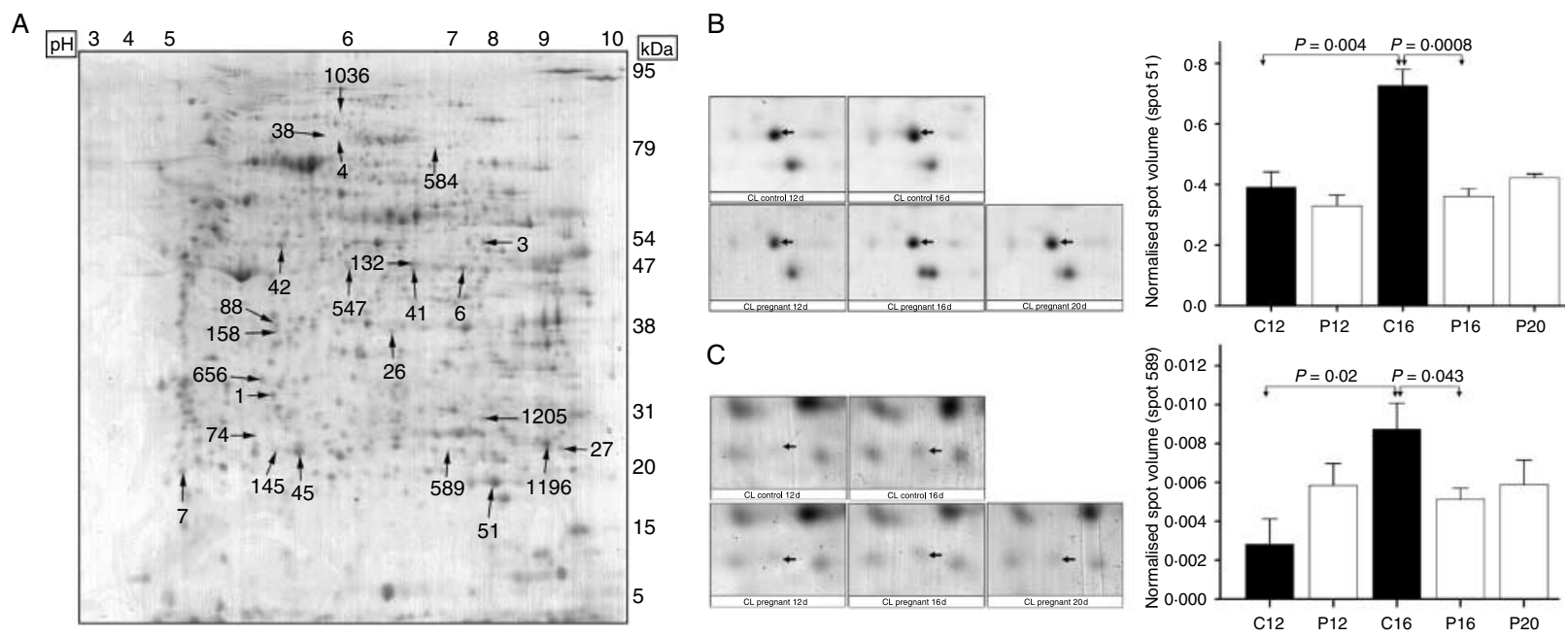

Figure 2 Representative grey-scale images of the CL proteome: (A) CL proteins separated by 2DE gel using a 3-10 $\mathrm{pH}$ gradient (control on day 16: C16). Differentially expressed proteins that were identified by LC-MS/MS are indicated by arrows with the spot numbers. (B) The montage showing spot number 51 (SOD2) indicated by black arrows with expression levels summarised in the histogram. There were significant differences in SOD2 expression between CL of cyclic ewes on days 12 and 16 also between CL of cyclic and pregnant ewes at the time of implantation $(P<0 \cdot 05)$. (C) Spot number 589 (BLVRB) indicated by black arrows with expression levels summarised in the histogram. BLVRB expression significantly increased between $\mathrm{CL}$ of cyclic ewes on days 12 and $16(P<0 \cdot 05)$. BLVRB expressed in the CL of cyclic group on day 16 is higher than that in the CL of pregnant group at the same time. Normalised spot volumes are shown as mean \pm S.E.M. ( $n=4$ per group).

\section{Changes in CL proteins during early pregnancy}

In total, 52 protein spots were significantly $(P<0 \cdot 05)$ up-regulated and 14 down-regulated in CL of pregnant ewes at the time of implantation (day 16) compared with ewes on pre-implantation (day 12; Table 1). The smallest number of significant changes in protein spot volumes (13 upregulated spots and 24 down-regulated in the CL of pregnant ewes on day 20 compared with day $16, P<0 \cdot 05)$ occurred between days 16 and 20 of pregnancy (Table 1). The expression of FDXR increased (6.07-fold) between preimplantation and implantation; however, its expression fell at post-implantation (day 20; Table 2). The expression of GSTA1, ornithine aminotransferase, isoform 2 (OAT), GNB2 and MX1 significantly increased $(P<0 \cdot 05)$ between days 12 and 16 and tended to increase on day 20 (Table 2). The expression of APOA1 secreted highly during implantation and early pregnancy. In addition, expression of enoyl-CoA hydratase and mitochondrial (ECHS1) declined 4-26-fold $(P<0 \cdot 05)$ on day 20 compared with day 16 (Table 2 ).

\section{Divergent protein profiles in CL of pregnancy compared with CL of the oestrous cycle}

There were small but significant differences in the protein profiles between pregnant and cyclic groups on day 12 (P12 versus C12). At this stage, 21 normalised spot volumes were significantly $(P<0 \cdot 05)$ up-regulated and 15 down-regulated (Table 1) in CL of pregnant ewes compared with the matching day of the luteal phase of cyclic ewes. Furthermore, reduced expression of FDXR and LMNA was observed in the $\mathrm{CL}$ of pregnant ewes compared with the CL of cyclic ewes
(Table 2). The normalised volumes of 178 spots were significantly $(P<0.05)$ altered in CL of pregnant ewes at the time of implantation compared with matching stage of the luteal phase of cyclic ewes: 77 up-regulated and 101 downregulated in CL of pregnant ewes (Table 1). The expression of VIM and SOD2 (Fig. 2B) was higher (4.81- and 2.01-fold respectively, $P<0 \cdot 05)$ in $\mathrm{CL}$ of cyclic ewes compared with CL of pregnant ewes at the time of implantation (Table 2). In contrast, the expression of MX1 and APOA1 was markedly elevated (4.52- and 1.29-fold respectively, $P<0 \cdot 05)$ in CL of pregnant ewes. The expression of UQCRC1, FDXR, ANXA1 and BLVRB (Fig. 2C) was lower in the CL of pregnant ewes compared with cyclic ewes (Table 2). Comparing the P16 with C12 group enabled further analysis of differences between the pregnant and the non-pregnant but functional CL. Of the total protein spots, 51 were significantly

Table 1 Numbers of ovine corpus luteum protein spots significantly $(P<0 \cdot 05)$ differing between both control $(C)$ and pregnant $(\mathrm{P})$ groups during the oestrous cycle and early implantation

\section{Groups compared}

\begin{tabular}{|c|c|c|c|c|}
\hline Group & $\begin{array}{l}\text { Compared } \\
\text { with }\end{array}$ & $\begin{array}{l}\text { Up- } \\
\text { regulated }\end{array}$ & $\begin{array}{l}\text { Down- } \\
\text { regulated }\end{array}$ & $\begin{array}{l}\text { Percentage } \\
\text { of total } \\
\text { spots }\end{array}$ \\
\hline C16 & C12 & 139 & 69 & 15 \\
\hline P16 & P12 & 52 & 14 & 5 \\
\hline P20 & P16 & 13 & 24 & 3 \\
\hline P12 & C12 & 21 & 15 & 3 \\
\hline P16 & C16 & 77 & 101 & 13 \\
\hline P16 & C12 & 51 & 21 & 5 \\
\hline
\end{tabular}




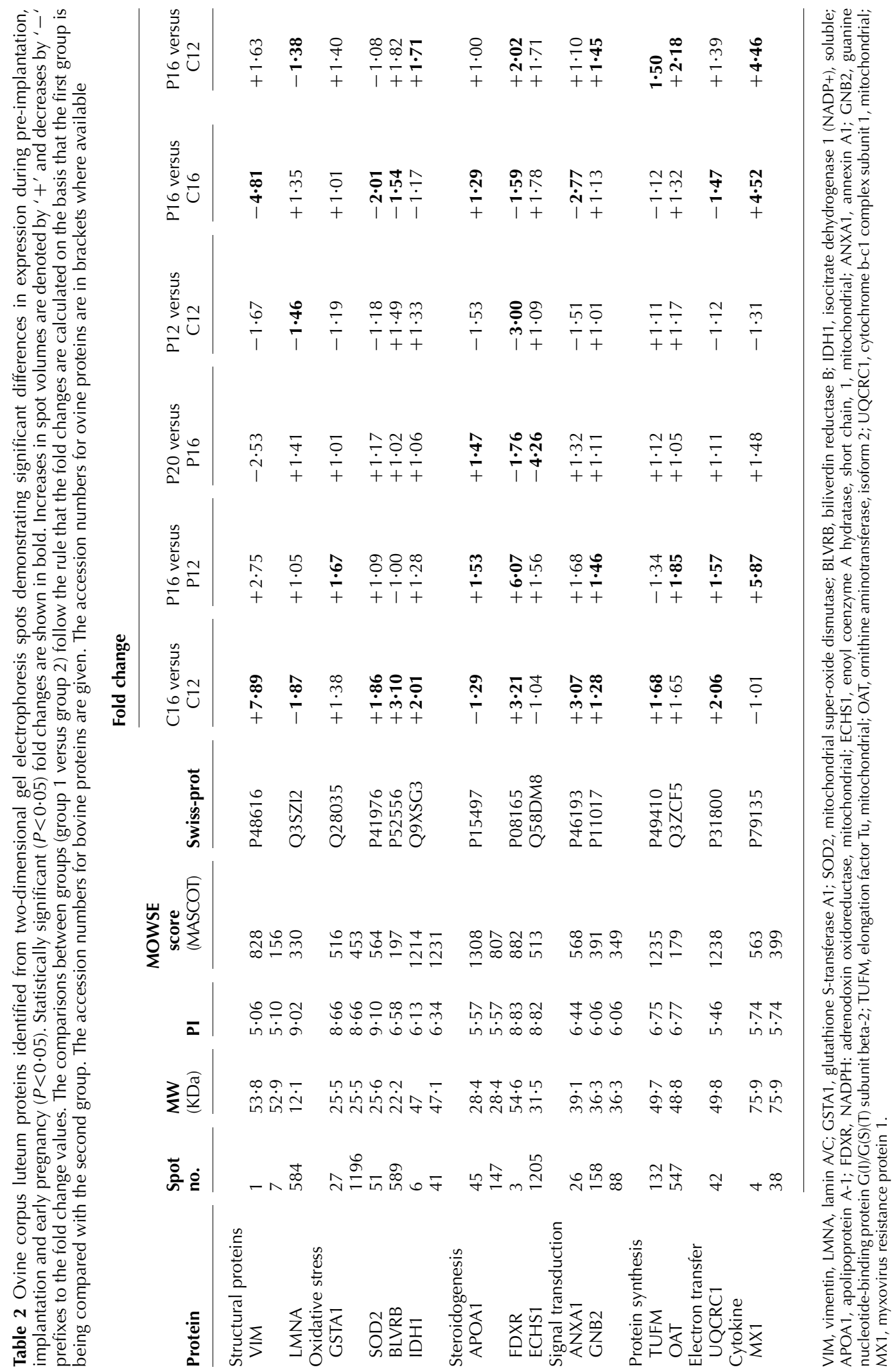


$(P<0 \cdot 05)$ up-regulated and 21 were down-regulated in the CL of pregnant ewes on day 16 compared with CL of cyclic ewes on day 12 (P16 versus C12; Table 1). The expression of IDH1, FDXR, GNB2, TUFM, OAT and MX1 was significantly $(P<0 \cdot 05)$ higher in the CL of pregnant ewes compared with cyclic ewes, whereas the expression of LMNA was significantly $(P<0 \cdot 05)$ lower in CL of pregnant ewes (Table 2).

\section{Validation of selected proteins}

It was not possible to identify all the protein spots of interest and representative examples were identified by LC-MS/MS. Tightly controlled reactive oxygen species (ROS) generation is an important constitutive process and is one of the central elements in cell signalling (Finkel 1998), gene expression (Allen \& Tresini 2000) and maintenance of redox homeostasis and signal transduction pathways involved in cell function, growth, differentiation and death (Valko et al. 2007). Therefore, immunohistochemistry was performed on two representative antioxidant proteins, SOD2 and BLVRB. These proteins are fundamental for CL function, especially during pregnancy (Sugino et al. 2000, Fang et al. 2004). They were also selected based on the availability of specific antibodies.

The expression of both SOD2 (Fig. 3A) and BLVRB (Fig. 3B) significantly increased $(P<0 \cdot 05)$ in the individual CL of cyclic ewes on day 16 compared with day 12 , that is in agreement with increased expression of these proteins at the late luteal phase in 2DE gel (Fig. 2B and C). The expression of both proteins by WB was greater $(P<0.05)$ in CL of cyclic ewes compared with CL of pregnant ewes on day 16 (Fig. 3A and B). SOD2, BLVRB and $3 \beta \mathrm{HSD}$ were immunolocalised in $\mathrm{CL}$ over peri-implantation periods. Positive SOD2 immunostaining was observed in all five groups in LCs and endothelial cells (Fig. 4A, left panel). BLVRB was localised to the cytoplasm of LLCs and SLCs (Fig. 4B, left panel). LLCs and SLCs showed 3BHSD-positive immunostaining compared with stromal cells, which were negative for $3 \beta \mathrm{HSD}$ (Fig. 4A, right panel; Fig. 4B, right panel). The pattern of immunostaining in CL from day 16 non-pregnant and pregnant ewes was similar to that shown in Fig. 4.

\section{Discussion}

We have demonstrated that $58 \%$ of detected protein spots in the ovine CL showed divergent expression during the periods of CL regression and maintenance. We identified 15 proteins with involvement in diverse CL functions including enzymatic antioxidant pathways and steroidogenesis, which are discussed below grouped by biological function.

\section{Oxidative stress}

ROS and antioxidant enzyme systems have been implicated in the regulation of reproductive processes, including ovarian
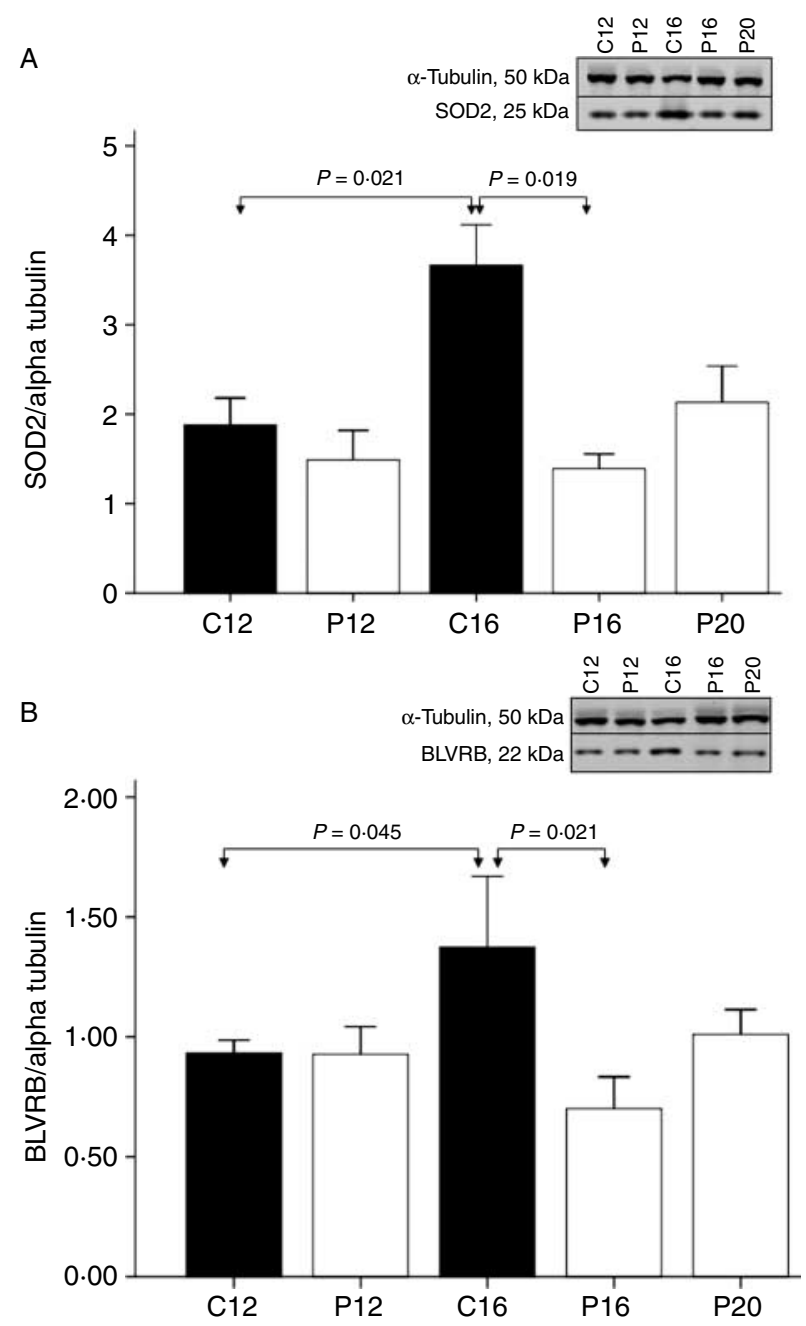

Figure 3 Western blot quantitation of two proteins identified from proteomic gel analysis. Each band is a representative band for a single CL. Band volumes normalised against $\alpha$-tubulin are shown as mean \pm S.E.M. ( $n=4$ per group). (A) SOD2 band volumes significantly increased $(P<0 \cdot 05)$ in the $\mathrm{CL}$ of cyclic ewes at the end of the oestrous cycle. SOD2 expression declined in the CL of pregnant ewes compared with the $\mathrm{CL}$ of cyclic ewes at the time of implantation $(P<0 \cdot 05)$. (B) BLVRB band volumes were significantly elevated in $C L$ of cyclic ewes from days 12 to 16 and significantly reduced in $\mathrm{CL}$ of pregnant ewes in comparison with $\mathrm{CL}$ of cyclic ewes across the implantation period $(P<0 \cdot 05)$.

follicular development, luteal steroidogenesis, endometrial receptivity and shedding, embryonic development and implantation (Al-Gubory et al. 2010). Cytosolic copper/ zinc-containing SOD (Cu, Zn-SOD or SOD1) and mitochondrial manganese-containing SOD2 contribute to the first line of antioxidant pathway defence against ROS. Our finding of a significant increase in SOD2 expression in ovine $\mathrm{CL}$ in the late luteal phase agrees with the previous findings that CL SOD2 activity increases from mid luteal to late luteal phase in women (Sugino et al. 2000) and sheep (Al-Gubory et al. 2005). Moreover, SOD2 expression in CLs 
A
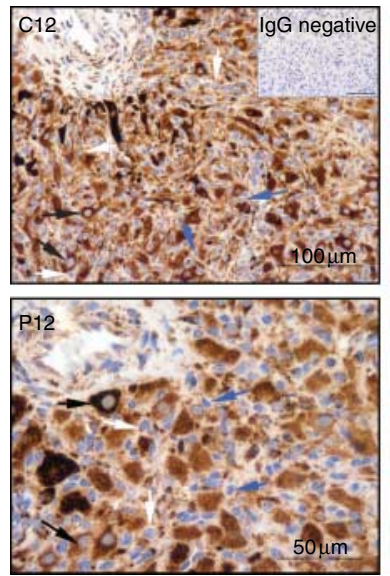


$\mathrm{B}$
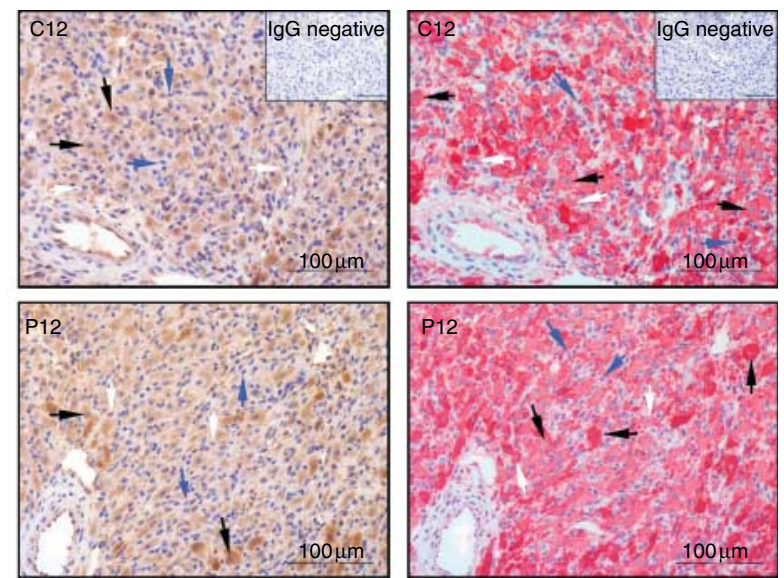

Figure 4 Representative immunohistochemical localisation of two proteins identified from proteomic gel analysis in the $\mathrm{CL}$ of $\mathrm{cyclic}$ and pregnant ewes. $3 \beta \mathrm{HSD}$ immunostaining in sections consecutive to SOD2 and BLVRB-immunostained sections is shown to highlight steroidogenic cells. (A) Left panel, SOD2 immunostaining; right panel, 3BHSD immunostaining. (B) Left panel, BLVRB immunostaining; right panel, 3ßHSD immunostaining. (C12) Cyclic ewe on day 12 (P12), pregnant ewe on day 12 (IgG negative), negative control (non-immune serum). Black arrows indicate large luteal cells (LLCs), white arrows show small luteal cells (SLCs) and blue arrows show stromal cells. Scale bars: (A; C12) and (B; C12, P12), $100 \mu \mathrm{m} ;(A ; P 12), 50 \mu \mathrm{m}$.

of pregnant ewes on days 12, 16 and 20 did not alter, in agreement with the previous findings for SOD2 activity (Al-Gubory et al. 2004). SOD2 mRNA is induced in the rat CL by inflammatory cytokines (Sugino et al. 1998), which are involved in CL regression (Niswender et al. 2000). Therefore, SOD2 expression increasing during the late luteal phase may be up-regulated by inflammatory cytokines.

GSTs are involved in the intracellular transport of compounds and their delivery to sites for subsequent transformation and/or excretion (Kaplowitz 1980) and are important in detoxifying reactive metabolites. GSTs are abundant in steroid-producing ovarian cells throughout the menstrual cycle (Rahilly et al. 1991), in bovine follicular and LC (Rabahi et al. 1999), and increase in activity during growth of porcine ovarian follicles and CL (Keira et al. 1994). GSTA1 is involved in detoxifying environmental toxins and products of oxidative stress (Ahn et al. 2006) and binds to steroid hormone metabolites, which it helps transport intracellularly (Listowsky et al. 1998). Increased expression of GSTA1 in CL from day 12 to day 16 of pregnancy (this study) is likely an important mechanism protecting the early developing CL against ROS-mediated cell damage. This agrees with the observations that ovine CL GST activity significantly increases from day 15 to day 40 of pregnancy (Al-Gubory et al. 2004).

BLVRB catalyses the conversion of biliverdin to bilirubin (McDonagh et al. 1981), which is a potent antioxidant (Stocker et al. 1987, Kwak et al. 1991). The depletion of cellular bilirubin increases ROS production and induces cell death by apoptosis (Baranano et al. 2002). The catalysing activity of BLVRB is an important mechanism in cellular signal transduction pathways, gene expression and oxidative response (Florczyk et al. 2008). The increased expression of
BLVRB in CL of cyclic ewes on day 16 compared with day 12 (present study) may be an adaptive response mechanism to overcome ROS-induced oxidative damage.

Maintaining cellular redox state is one of the primary functions of $\mathrm{NADP}^{+}$-dependent IDH1 (Lee et al. 2002). IDH1 abundance and activity in the immature rat ovary increased markedly following gonadotropin treatment (Jennings \& Stevenson 1991) and thus IDH1 may support ovarian development by maintaining cellular redox state and activities of ROS-scavenging enzymes. In our study, the expression of IDH1 tended to be more abundant in CL of cyclic rather than pregnant ewes at the time of implantation. However, in the absence of IDH1 activity data, this finding requires further study.

\section{Steroidogenesis}

High-density lipoprotein (HDL) is a main substrate for luteal steroidogenesis in rodents (Plump et al. 1996), human (Azhar et al. 1998) and pig (Miranda-Jiménez \& Murphy 2007). The bovine CL synthesises APOA1, the main component of HDL, across the oestrous cycle and pregnancy (NdikumMoffor et al. 1997). Thus, APOA1 stimulates $\mathrm{P}_{4}$ production in the $\mathrm{CL}$ and promotes $\mathrm{PGE}_{2}$ production (a luteotrophic $\mathrm{PG}$ ) (Chandras et al. 2004). In our study, APOA1 decreased from early to late luteal phase during CL regression but was highly expressed in the early CL of pregnancy at the time of embryo implantation (day 16) and post-implantation (day 20). The elevated expression of APOA1 in sheep CL during early pregnancy may, therefore, be related to the high demand for HDL required for $\mathrm{P}_{4}$ production.

The rate-limiting step in steroidogenesis is the conversion of cholesterol to pregnenolone by CYP11A, in which 
electrons are driven from NADPH through an electron transfer chain, consisting of FDXR and adrenodoxin (Hanukoglu 1996). The concentration of FDXR in porcine granulosa cells markedly increased during follicle growth and luteinisation (Tuckey \& Stevenson 1986). Similarly, FDXR increases in growing CL of cow (Hanukoglu \& Hanukoglu 1986) and rat (McLean et al. 1992), indicating increased CL steroidogenic activity due to FDXR induction. In this study, however, FDXR was, unexpectedly, more abundant during the late luteal phase in CL of cyclic ewes relative to CL of early pregnancy. In addition, FDXR expression increased in CL of pregnant ewes at the time of implantation (day 16) compared with pre-implantation (day 12). Surprisingly, there was a reduction in FDXR expression in CL of early pregnancy (present study), at a time when $\mathrm{P}_{4}$ secretion is essential. This might be due to the presence of an inactive form of FDXR, or masking of true abundance by other proteins in the particular protein spot.

\section{Signal transduction and apoptosis}

ANXA1 plays a role in phospholipase A2 activity (Solito et al. 2003), as well as mediating apoptosis (Petrella et al. 2005). Therefore, it is logical that ANXA1 was dramatically up-regulated in the regressed $\mathrm{CL}$ in comparison with the functional CL (this study). On day 12 of pregnancy, the rat ovary expresses lower ANXA5 mRNA levels than in pseudopregnancy. Therefore, $\mathrm{P}_{4}$ may down-regulate ANXA5 expression because the CL on day 12 of pregnancy secretes large amounts of $\mathrm{P}_{4}$, although the pseudopregnant $\mathrm{CL}$ is regressed (Kawaminami et al. 2003). The sheep CL exhibits higher apoptotic DNA fragmentation during the late luteal phase than in early and mid luteal phase, concomitantly with a diminution in the plasma $\mathrm{P}_{4}$ concentrations from mid to late luteal phase (Al-Gubory et al. 2005). Thus, high expression of ANXA1 in the regressed CL (present study) is likely because $\mathrm{P}_{4}$ titres at the late luteal stage are inadequate to maintain ANXA1, contributing to a subsequent increase in apoptosis.

GNB2 has GTPase activity, participating in G proteincoupled receptor activity (Hamm 1998). Elevation of GNB2 expression in regressed CL (this study) is likely due to increased $\mathrm{PGF}_{\alpha}$ levels during the late luteal phase. $\mathrm{PGF}_{\alpha}$, a stimulator of apoptosis in the sheep CL (Garrel et al. 2007), exerts its function through a $\mathrm{G}$ protein-coupled receptor on LCs. Thus, it can activate the $\mathrm{Gq} /$ phospholipase C/protein kinase $\mathrm{C}$ pathway, leading to a reduction in steroidogenesis (Yadav et al. 2005). In addition, GNB2 was highly expressed in $\mathrm{CL}$ at the time of implantation and early pregnancy (this study), possibly due to binding of LH to its $\mathrm{G}$ protein-coupled receptor on the LCs. This may result in the activation of cAMP/PKA signalling pathway that plays a role in the regulation of steroidogenesis (Chin \& Abayasekara 2004, Stocco et al. 2007).

VIM may be involved in apoptosis, as a candidate substrate of caspase-mediated proteolysis (Prasad et al. 1999). Although VIM expression in the rat CL did not change during the luteal life span (Nilsson et al. 1995), it was markedly increased in the regressed ovine CL (this study). We suggest that VIM may participate in LCs apoptosis, a major factor in the control of CL formation, function and regression (Stocco et al. 2007).

\section{Protein synthesis}

OAT is involved in the synthesis of polyamines (Wu et al. 2005), which play key roles in protein synthesis and cell proliferation and differentiation (Igarashi \& Kashiwagi 2000). OAT activity in the porcine placenta was elevated during early pregnancy, reflecting the synthesis of polyamines essential for conceptus development through ornithine decarboxylase (ODC), a key enzyme in polyamine biosynthesis (Wu et al. 2004, 2005). Inhibition of the preovulatory rise of ovarian ODC leads to a decrease in CL $\mathrm{P}_{4}$ synthesis during the murine oestrous cycle (Bastida et al. 2002). In our study, OAT was most abundant in CL during early pregnancy. We propose that OAT plays a role in the steroidogenic pathway of ovine CL. This is supported by the fact that the OAT protein expression did not change from day 12 to day 16 of the oestrous cycle (this study).

\section{Miscellaneous functions}

MX proteins are anti-viral GTPases induced by cytokines, in particular type I IFNs (Thomas et al. 2006). MX mRNA expression is stimulated in the sheep endometrium (Charleston \& Stewart 1993) and CL (Spencer et al. 1999) by IFN- $\tau($ IFN $\tau)$. This is the ovine conceptus trophoblast signal for maternal recognition pregnancy between days 10 and 20 of pregnancy, with maximum production at the time of implantation (Gray et al. 2006). MX is highly expressed in the endometrium between days 13 and 20 of sheep pregnancy (Charleston \& Stewart 1993). In this study, MX1 increased at the time of implantation and remained at high abundance during early pregnancy. Logically, this is due to MX1 induction by IFN $\tau$ because IFN $\tau$ can exert its effects: 1) directly on the CL, 2) indirectly via some mediators such as chemokines and 3) systemically by circulating immune system. Although MX1's function in the CL is not yet understood, it may participate in modulating immune system activity.

It is very difficult to characterise the entire luteal proteome because of the very large number of proteins contained in tissue lysates. Furthermore, one of the main limitations of the current proteomic technology is that low-abundance proteins in biological samples cannot be easily detected during the analysis of the proteome. Proteomics identifies alterations in proteins, thus further studies are required to determine whether those changes are of functional significance or due to tissue remodelling, for instance. Furthermore, most antibodies are not isoform specific. Therefore, where the 2DE gels yielded specific isoforms separately, the WB reflected total immunoreactive quantities of the protein and this may cause a disconnect between the $2 \mathrm{DE}$ and the $\mathrm{WB}$ 
quantitations of proteins. Nevertheless, although there are limitations to the 2DE gel-based proteomic analysis, we have identified novel proteins, with potentially relevant biological functions, in ovine CL.

In conclusion, 2DE gel and mass spectrometry have been used for the first time to study ovine CL function. We have identified proteins involved in key pathways, including oxidative stress, steroidogenesis, signal transduction, and apoptosis, which have not previously been associated with changes occurring in the CL during the peri-implantation period. These proteins are most likely involved with mechanisms allowing rescue of the CL and maintenance of $\mathrm{P}_{4}$ production during early pregnancy.

\section{Declaration of interest}

The authors declare that there is no conflict of interest that could be perceived as prejudicing the impartiality of the research reported.

\section{Funding}

This project was funded by NHS Grampian R\&D project number RG05/019.

\section{Acknowledgements}

We are grateful to M Fraser, I Davidson, E Stewart and E Argo for their expert technical assistance and to Dr P Cash for his proteomic advice (all IMS, University of Aberdeen). The authors thank the staff of the sheep sheds of Broueëssy and Jouy-en-Josas (INRA, France) for their outstanding technical help and sheep management. We also thank Prof. P Papa from the University of Sao Paulo because of her excellent guidance in the immunohistochemistry of CL and Prof. J I Mason, University of Edinburgh, for providing $3 \beta$ HSD antibody.

\section{References}

Ahn J, Gammon MD, Santella RM, Gaudet MM, Britton JA, Teitelbaum SL, Terry MB, Neugut AI, Eng SM, Zhang Y et al. 2006 Effects of glutathione S-transferase A1 (GSTA1) genotype and potential modifiers on breast cancer risk. Carcinogenesis 27 1876-1882. (doi:10.1093/carcin/bgl038)

Al-Gubory KH, Solari A \& Mirman B 1999 Efects of luteectomy on the maintenance of pregnancy, circulating progesterone concentrations and lambing performance in sheep. Reproduction, Fertility, and Development 11 317-322. (doi:10.1071/RD99079)

Al-Gubory KH, Bolifraud P, Germain G, Nicole A \& Ceballos-Bicot I 2004 Antioxidant enzymatic defence systems in sheep corpus luteum throughout pregnancy. Reproduction 128 767-774. (doi:10.1530/rep.1.00389)

Al-Gubory KH, Ceballos-Picot I, Nicole A, Bolifraud F, Germain G, Michaud M, Mayeur C \& Blachier F 2005 Changes in activities of superoxide dismutase, nitric oxide synthase, glutathione-dependent enzymes and the incidence of apoptosis in sheep corpus luteum during the estrous cycle. Biochimica et Biophysica Acta 1725 348-357. (doi:10.1016/ j.bbagen.2005.06.018)

Al-Gubory KH, Camous S, Germain G, Bolifraud P, Nicole A \& CeballosPicot I 2006 Reconsideration of the proposed luteotropic and luteoprotective actions of ovine placental lactogen in sheep: in vivo and in vitro studies. Journal of Endocrinology 188 559-568. (doi:10.1677/joe.1.06550)
Al-Gubory KH, Fowler PA \& Garrel C 2010 The roles of cellular reactive oxygen species, oxidative stress and antioxidants in pregnancy outcomes. International Journal of Biochemistry and Cell Biology 42 1634-1650. (doi:10. 1016/j.biocel.2010.06.001)

Allen RG \& Tresini M 2000 Oxidative stress and gene regulation. Free Radical Biology and Medicine 28 463-499. (doi:10.1016/S0891-5849(99)00242-7)

Arredondo F \& Noble LS 2006 Endocrinology of recurrent pregnancy loss. Seminars in Reproductive Medicine 24 33-39. (doi:10.1055/s-2006-931799)

Azhar S, Tsai L, Medicherla S, Chandrasekher Y, Giudice L \& Reaven E 1998 Human granulosa cells use high density lipoprotein cholesterol for steroidogenesis. Journal of Clinical Endocrinology and Metabolism 83 983-991. (doi:10.1210/jc.83.3.983)

Baranano DE, Rao M, Ferris CD \& Snyder SH 2002 Biliverdin reductase: a major physiologic cytoprotectant. PNAS 99 16093-16098. (doi:10.1073/ pnas.252626999)

Bastida CM, Tejada F, Cremades A \& Peñafiel R 2002 The preovulatory rise of ovarian ornithine decarboxylase is required for progesterone secretion by the corpus luteum. Biochemical and Biophysical Research Communications 293 106-111. (doi:10.1016/S0006-291X(02)00191-2)

Cash P \& Kroll JS 2003 Protein charactrization by two-dimensional gel electrophoresis. Methods in Molecular Medicine 71 101-118. (doi:10.1385/ 1-59259-321-6:101)

Chandras C, Ragoobir J, Barrett GE, Bruckdorfer KR, Grahama A, Abayasekara DRE \& Michael AE 2004 Roles for prostaglandins in the steroidogenic response of human granulosa cells to high-density lipoproteins. Molecular and Cellular Endocrinology 222 1-8. (doi:10.1016/j. mce.2004.05.008)

Charleston B \& Stewart HJ 1993 An interferon-induced mx protein: CDNA sequence and high-level expression in the endometrium of pregnant sheep. Gene 137 327-331. (doi:10.1016/0378-1119(93)90029-3)

Chin EC \& Abayasekara DRE 2004 Progesterone secretion by luteinizing human granulosa cells: a possible cAMP-dependent but PKA-independent mechanism involved in its regulation. Journal of Endocrinology 183 51-60. (doi:10.1677/joe.1.05550)

Csapo AL, Pulkkinen MO, Ruttner B, Sauvage JP \& Wiest WG 1972 The significance of the human corpus luteum in pregnancy maintenance. I. Preliminary studies. American Journal of Obstetrics and Gynecology 112 1061-1067.

Diskin MG \& Morris DG 2008 Embryonic and early foetal losses in cattle and other ruminants. Reproduction in Domestic Animals 43 260-267. (doi:10. 1111/j.1439-0531.2008.01171.x)

Estergreen VL, Frost OL, Gomes WR, Erb RE \& Bullard JF 1967 The effect of ovariectomy on pregnancy maintenance and parturition in dairy cows. Journal of Dairy Science 50 1293-1295. (doi:10.3168/jds.S00220302(67)87615-X)

Fang J, Akaike T \& Maeda H 2004 Antiapoptotic role of heme oxygenase $(\mathrm{HO})$ and the potential of $\mathrm{HO}$ as a target in anticancer treatment. Apoptosis 9 27-35. (doi:10.1023/B:APPT.0000012119.83734.4e)

Finkel T 1998 Oxygen radicals and signaling. Current Opinion in Cell Biology 10 248-253. (doi:10.1016/S0955-0674(98)80147-6)

Florczyk UM, Jozkowicz A \& Dulak J 2008 Biliverdin reductase: new features of an old enzyme and its potential therapeutic significance. Pharmacological Reports $6038-48$.

Fowler PA, Tattum J, Bhattacharya S, Klonisch T, Hombach-Klonisch S, Gazvani R, Lea RG, Miller I, Simpson WG \& Cash P 2007 An investigation of the effects of endometriosis on the proteome of human eutopic endometrium: a heterogeneous tissue with a complex disease. Proteomics 7 130-142. (doi:10.1002/pmic.200600469)

Fowler PA, Dora NJ, McFerran H, Amezaga MR, Miller DW, Lea RG, Cash P, McNeilly AS, Evans NP, otinot C et al. 2008 In utero exposure to low doses of environmental pollutants disrupts fetal ovarian developmental in sheep. Molecular Human Reproduction 14 269-280. (doi:10.1093/ molehr/gan020)

Garrel C, Ceballos-Picot I, Germain G \& Al-Gubory KH 2007 Oxidative stress-inducible antioxidant adaptive response during prostaglandin $\mathrm{F}_{2 \alpha}$-induced luteal cell death in vivo. Free Radical Research 41 251-259. (doi:10.1080/10715760601067493) 
Gonzalez-Fernandez R, Martinez-Galisteo E, Gaytan F, Barcena JA \& Snchez-Criado JE 2008 Changes in the proteome of functional and regressing corpus luteum during pregnancy and lactation in the rat. Biology of Reproduction 79 100-114. (doi:10.1095/biolreprod.107.065474)

Gray CA, Abbey CA, Beremand PD, Choi Y, Farmer JL, Adelson DL, Thomas TL, Bazer FW \& Spencer TE 2006 Identification of endometrial genes regulated by early pregnancy, progesterone, and interferon tau in the ovine uterus. Biology of Reproduction 74 384-394. (doi:10.1095/biolreprod. 105.046656)

Hamm HE 1998 The many faces of G protein signaling. Journal of Biological Chemistry 273 669-672. (doi:10.1074/jbc.273.2.669)

Hanukoglu I 1996 Electron transfer proteins of cytochrome P450 systems. Advanced Molecular Cell Biology 14 29-55. (doi:10.1016/S15692558(08)60339-2)

Hanukoglu I \& Hanukoglu Z 1986 Stoichiometry of mitochondrial cytochromes P-450, adrenodoxin and adrenodoxin reductase in adrenal cortex and corpus luteum implications for membrane organization and gene regulation. European Journal of Biochemistry 157 27-31. (doi:10.1111/j. 1432-1033.1986.tb09633.x)

Igarashi K \& Kashiwagi K 2000 Polyamines: mysterious modulators of cellular functions. Biochemical and Biophysical Research Communications 271 559-564. (doi:10.1006/bbrc.2000.2601)

Jennings GT \& Stevenson PM 1991 A study of the control of NADP ${ }^{+}$dependent isocitrate dehydrogenase activity during gonadotropin-induced development of the rat ovary. European Journal of Biochemistry 198 621-625. (doi:10.1111/j.1432-1033.1991.tb16059.x)

Kaplowitz N 1980 Physiological significance of glutathione-S-transferases. American Journal of Physiology 239 G439-G444.

Kawaminami M, Shibata Y, Yaji A, Kurusu S \& Hashimoto I 2003 Prolactin inhibits annexin 5 expression and apoptosis in the corpus luteum of pseudopregnant rats: involvement of local gonadotropin-releasing hormone. Endocrinology 8 3625-3631. (doi:10.1210/en.2003-0118)

Keira M, Nishihira J, Ishibashi T, Tanaka T \& Fujimoto S 1994 Identification of a molecular species in porcine ovarian luteal glutathione S-transferase and its hormonal regulation by pituitary gonadotropins. Archives of Biochemistry and Biophysics 308 126-132. (doi:10.1006/abbi.1994.1018)

Kwak JY, Takeshige K, Cheung BS \& Minakami S 1991 Bilirubin inhibits the activation of superoxide-producing NADPH oxidase in a neutrophil cellfree system. Biochimica et Biophysica Acta 1076 369-373. (doi:10.1016/01674838(91)90478-I)

Lee SM, Koh H, Park D, Song BJ, Huh T \& Park J 2002 Cytosolic NADP ${ }^{+}$dependent isocitrate dehydrogenase status modulates oxidative damage to cells. Free Radical Biology and Medicine 32 1185-1196. (doi:10.1016/S08915849(02)00815-8)

Listowsky I, Abramovitz M, Homma H \& Niitsu Y 1998 Intracellular binding and transport of hormones and xenobiotics by glutathione S-transferases. Drug Metabolism Reviews 19 305-318. (doi:10.3109/03602538808994138)

Mann M \& Jensen ON 2003 Proteomic analysis of post-translational modifications. Nature Biotechnology 21 255-261. (doi:10.1038/nbt0303255)

McDonagh AF, Palma LA \& Schmid R 1981 Reduction of biliverdin and placental transfer of bilirubin and biliverdin in the pregnant guinea pig. Biochemical Journal 194 273-282.

McLean MP, Nelson SE, Billeimer JT \& Giborit G 1992 Differential capacity for cholesterol transport and processing in large and small rat luteal cells. Endocrinology 131 2203-2212. (doi:10.1210/en.131.5.2203)

Miranda-Jiménez L \& Murphy BD 2007 Lipoprotein receptor expression during luteinization of the ovarian follicle. American Journal of Physiology. Endocrinology and Metabolism 293 E1053-E1061. (doi:10.1152/ajpendo. 00554.2006)

Mitwally M, Casper RF \& Diamond MP 2005 The role of aromatase inhibitors in ameliorating deleterious effects of ovarian stimulation on outcome of infertility treatment. Reproductive Biology and Endocrinology 354. (doi:10.1186/1477-7827-3-54)

Murdoch WJ \& Van Kirk EA 1998 Luteal dysfunction in ewes induced to ovulate early in the follicular phase. Endocrinology 139 3480-3484. (doi:10. $1210 /$ en.139.8.3480)
Ndikum-Moffor FM, Simmen RCM, Fields PA, Katoh N, Oikawa S, Buhi WC, Rollyson MK, Chang ST \& Fields MJ 1997 Synthesis and messenger ribonucleic acid expression of apolipoproteins E and A-I by the bovine corpus luteum during the estrous cycle and pregnancy. Biology of Reproduction 56 745-756. (doi:10.1095/biolreprod56.3.745)

Nilsson I, Mattsson MO \& Selstam G 1995 Presence of the intermediate filaments cytokeratins and vimentin in the rat corpus luteum during luteal life-span. Histochemistry 103 237-242. (doi:10.1007/BF01454029)

Niswender GD, Juengel JL, Silva PJ, Rollyson MK \& McIntush EW 2000 Mechanisms controlling the function and life span of the corpus luteum. Physiological Reviews 80 1-29.

O'Shea JD, Crant DG \& Hay MF 1979 The small luteal cell of the sheep. Journal of Anatomy 128 239-251.

Petrella A, Festa M, Ercolino SF, Zerilli M, Stassi G, Solito E \& Parente L 2005 Induction of annexin-1 during TRAIL induced apoptosis in thyroid carcinoma cells. Cell Death and Differentiation 12 1358-1360. (doi:10.1038/ sj.cdd.4401645)

Plump AS, Erickson SK, Weng W, Partin JS, Breslow JL \& Williams DL 1996 Apolipoprotein A-I is required for cholesteryl ester accumulation in steroidogenic cells and for normal adrenal steroid production. Journal of Clinical Investigation 97 2660-2671. (doi:10.1172/JCI118716)

Porter TF \& Scott JR 2005 Evidence-based care of recurrent miscarriage. Best Practice and Research. Clinical Obstetrics \& Gynaecology 19 85-101. (doi:10.1016/j.bpobgyn.2004.11.005)

Prasad S, Soldatenkov VA, Srinivasarao G \& Dritschilo A 1999 Intermediate filament proteins during carcinogenesis and apoptosis. International Journal of Oncology 14 563-570.

Rabahi F, Brûlé S, Sirois J, Beckers JF, Silversides DW \& Lussier JG 1999 High expression of bovine (glutathione S-transferase (GSTA1, GSTA2) subunits is mainly associated with steroidogenically active cells and regulated by gonadotropins in bovine ovarian follicles. Endocrinology 140 3507-3517. (doi:10.1210/en.140.8.3507)

Rahilly M, Carder PJ, Al Nafussi A \& Harrison DJ 1991 Distribution of glutathione S-transferase isoenzymes in human ovary. Journal of Reproduction and Fertility 93 303-311. (doi:10.1530/jrf.0.0930303)

Ryan RJ 1969 Theoretical basis for endocrine control of gestation. A comparative approach. In Proceedings of the International Symposium, Milan, Italy, pp 120-131. Eds A Pécile \& C Finzi. Amesterdam: Excerpta Medica Foundation.

Schanbacher BD 1979 Radioimmunoassay of ovine and bovine serum progesterone without extraction and chromatography. Endocrine Research Communications 6 265-277. (doi:10.1080/07435807909061106)

Schlafke S \& Enders AC 1975 Cellular basis of interaction between trophoblast and uterus at implantation. Biology of Reproduction 12 41-65. (doi:10.1095/biolreprod12.1.41)

Silva E, O'Gorman M, Becker S, Auer G, Eklund A, Grunewald J \& Wheelock AM 2010 In the eye of the beholder: does the master see the samespots as the novice? Journal of Proteome Research 9 1522-1532. (doi:10. 1021/pr9010298)

Solito E, Kamal A, Russo-Marie F, Buckingham JC, Marullo S \& Perretti M 2003 A novel calcium-dependent proapoptotic effect of annexin 1 on human neutrophils. FASEB Journal 17 1544-1546. (doi:10.1096/ fj.02-0941fje)

Spencer TE, Stagg AG, Ott L, Johnson GA, Ramsey WS \& Bazer FW 1999 Differential effects of intrauterine and subcutaneous administration of recombinant ovine interferon tau on the endometrium of cyclic ewes. Biology of Reproduction 61 464-470. (doi:10.1095/biolreprod61.2.464)

Stephens AN, Hannan NJ, Rainczuk A, Meehan KL, Chen J, Nicholls PK, Rombauts LJF, Stanton PG, Robertson DM \& Salamonsen LA 2010 Posttranslational modifications and protein-specific isoforms in endometriosis revealed by 2D DIGE. Journal of Proteome Research 9 2438-2449. (doi:10. $1021 /$ pr901131p)

Stocco C, Telleria C \& Gibori G 2007 The molecular control of corpus luteum formation, function, and regression. Endocrine Reviews 28 117-149. (doi:10.1210/er.2006-0022)

Stocker R, Yamamoto Y, McDonagh AF, Glazer AN \& Ames BN 1987 Bilirubin is an antioxidant of possible physiological importance. Science 235 1043-1046. (doi:10.1126/science.3029864) 
Sugino N, Telleria CM \& Gibori G 1998 Differential regulation of copperzinc superoxide dismutase and manganese superoxide dismutase in the rat corpus luteum: induction of manganese superoxide dismutase messenger ribonucleic acid by inflammatory cytokines. Biology of Reproduction 59 208-215. (doi:10.1095/biolreprod59.1.208)

Sugino N, Takiguchi S, Kashida S, Karbue A, Nakamura Y \& Kato H 2000 Superoxide dismutase expression in the human corpus luteum during the menstrual cycle and early pregnancy. Molecular Human Reproduction 619-25. (doi:10.1093/molehr/6.1.19)

Tavaniotou A, Albano C, Smitz J \& Devroey P 2002 Impact of ovarian stimulation on corpus luteum function and embryonic implantation. Journal of Reproductive Immunology 55 123-130. (doi:10.1016/S01650378(01)00134-6)

Thomas AV, Palm M, Broers AD, Zezafoun H \& Desmecht DJM 2006 Genomic structure, promoter analysis, and expression of the porcine (Sus scrofa) Mx1 gene. Immunogenetics 58 383-389. (doi:10.1007/s00251-0060109-2)

Tuckey RC \& Stevenson PM 1986 Ferredoxin reductase levels in the ovaries of pigs and superovulated rats during follicular cell growth and luteinization. European Journal of Biochemistry 161 629-633. (doi:10.1111/j.1432-1033. 1986.tb10487.x)

Uwins C, Deitrich C, Argo EA, Stewart EC, Davidson I \& Cash P 2006 Growth-induced changes in the proteome of Helicobacter pylori. Electrophoresis 27 1136-1146. (doi:10.1002/elps.200500655)

Valko M, Leiter D, Moncol J, Cronin MTD, Mazur M \& Telser J 2007 Free radicals and antioxidants in normal physiological functions and human disease. International Journal of Biochemistry and Cell Biology 39 44-84. (doi:10.1016/j.biocel.2006.07.001)
Vonnahme KA, Redmer DA, Borowczyk E, Bilski JJ, Luther JS, Johnson ML, Reynolds LP \& Grazul-Bilska AT 2006 Vascular composition, apoptosis, and expression of angiogenic factors in the corpus luteum during prostaglandin $\mathrm{F}_{2 \alpha}$-induced regression in sheep. Reproduction 131 1115-1126. (doi:10.1530/rep.1.01062)

Wathes DC 1992 Embryonic mortality and the uterine environment. Journal of Endocrinology 134 321-325. (doi:10.1677/joe.0.1340321)

Webb R, Woad KJ \& Armestrong DG 2002 Corpus luteum (CL) function: local control mechanisms. Domestic Animal Endocrinology 23 277-285. (doi:10.1016/S0739-7240(02)00163-7)

Wu G, Bazer FW, Cudd TA, Meininger CJ \& Spencer TE 2004 Maternal nutrition and fetal development. Journal of Nutrition 134 2169-2172.

Wu G, Bazer FW, Hu J, Johnson GA \& Spencer TE 2005 Polyamine synthesis from proline in the developing porcine placenta. Biology of Reproduction 72 842-850. (doi:10.1095/biolreprod.104.036293)

Yadav VK, Lakshmi G \& Medhamurthy R 2005 Prostaglandin $\mathrm{F}_{2 \alpha}$-mediated activation of apoptotic signaling cascades in the corpus luteum during apoptosis: involvement of caspase activated DNase. Journal of Biological Chemistry 280 10357-10367. (doi:10.1074/jbc. M409596200)

\section{Received in final form 25 March 2011 \\ Accepted 8 April 2011 \\ Made available online as an Accepted Preprint 8 April 2011}

